Fourth International Conference on Sustainable Construction Materials and Technologies http://www.claisse.info/Proceedings.htm

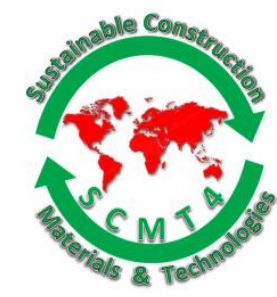

SCMT4

Las Vegas, USA, August 7-11, 2016

\title{
Mechanical Properties of Steel Fiber Reinforced Concrete Damaged by ASR and Subsequent Corrosion of Steel Fiber
}

\author{
Sara Farooq ${ }^{1 \mathrm{a}}$, Hiroshi Yokota ${ }^{1 \mathrm{~b}}$, and Katsufumi Hashimoto ${ }^{1 \mathrm{c}}$ \\ ${ }^{1}$ Graduate School of Engineering, Hokkaido University, Kita 13, Nishi 8, Kita-ku, Sapporo, Hokkaido \\ 060-8628, Japan. ${ }^{1 a}$ Email: <farooq692@gmail.com>, ${ }^{1 b}$ Email: 〈yokota@eng.hokudai.ac.jp>, \\ ${ }^{1 c}$ Email: <hashimoto.k@eng.houdai.ac.jp>.
}

\begin{abstract}
This research aims at empirically investigating the mechanical properties of steel fiber reinforced concrete damaged due to alkali silica reaction (ASR) and subsequent corrosion due to chloride ion penetration. Twenty seven prisms and fifty four cylinders were prepared for the experiments. The specimens were consisted of three types of concrete: plain concrete (control) and two types of fiber reinforced concrete: SFRC and UHSFRC comprised of normal and ultra-high strength steel fibers, respectively. Temperature ranges of $5{ }^{\circ} \mathrm{C}, 25^{\circ} \mathrm{C}$ and $40^{\circ} \mathrm{C}$ were used in the experiment. The experimental setup consisted of two steps. Specimens cured in water for 14 days were exposed to $1 \mathrm{~N} \mathrm{NaOH}$ solution followed by submersion in $3 \%$ $\mathrm{NaCl}$ solution for ten weeks each. This was done to facilitate chloride ion ingress. An increase in compressive strength and split tensile strength for ASR and chloride damaged specimens was observed. Comparison of first crack strength reduction, for ASR and chloride deteriorated prisms showed better performance in case of SFRC and UHSFRC than that in the plain concrete by $9 \%, 4.7 \%$ at $5^{\circ} \mathrm{C}$ and $6.8 \%$ and $20.3 \%$ at $40{ }^{\circ} \mathrm{C}$. Whereas at $25{ }^{\circ} \mathrm{C}$, SFRC and UHSFRC showed minimal differences in strength loss; $2.12 \%$ and $0.28 \%$ as compared compared to plain concrete. An increase in first crack strength for ASR damaged specimens ranging between $2.25 \%$ to $35 \%$; followed by reduction for coupled effect of ASR and chloride environment ranging between $4.7 \%$ to $26 \%$ is discussed.
\end{abstract}

\section{INTRODUCTION}

Alkali silica reaction (ASR) is one of the major deterioration processes in reinforced concrete structures which affects the material and mechanical properties. This results in decreased strength, stiffness and increased permeability leading to loss in durability and premature failure in structures. ASR is initiated with the presence of sufficient alkalis $\left(\mathrm{Na}_{2} \mathrm{O}\right.$ and $\left.\mathrm{K}_{2} \mathrm{O}\right)$, reactive silica and enough moisture content. ASR gel is the result of reaction between hydroxyl ions from portland cement hydration and amorphous silica in the aggregate in the presence of moisture. The ASR gel ingurgitates surrounding moisture and expands. This exerts internal stresses at the mortar-aggregate interface which then induces cracking in concrete.

The reactive forms of silica such as opal (amorphous), chalcedony (cryptocrystalline fibrous) and tridymite (crystalline) are susceptible to cause ASR [Neville 1981]. Moreover, it is considered that more than $0.6 \%$ alkali content $\left(\mathrm{Na}_{2} \mathrm{O}_{\text {eq }}\right)$ in cement can cause expansive reaction in concrete. In practice the use of low alkali cement $\left(\mathrm{Na}_{2} \mathrm{O}_{\mathrm{eq}}<0.6 \%\right.$, ASTM C 150) with a reactive aggregate is recommended to control ASR expansion 
[Farny and Kerkhoff 2007]. In contrast, the use of low alkali cement may not effectively prevent alkali aggregate reaction in severe alkaline environment [Swamy and Al-Asali 1990]. There are various test methods such as rapid mortar bar test methods [ASTM C 1260; AASHTO T 303], petrographic examination [ASTM C 295] and chemical methods [ASTM C 289] to evaluate the potential reactivity of aggregate. The total alkali content in concrete $\left(\mathrm{Na}_{2} \mathrm{O}_{\text {eq }}\right)$ is another guideline to avoid deleterious expansion provided it does not exceed $3 \mathrm{~kg} / \mathrm{m}^{3}$. The effect of environmental and exposure conditions such as relative humidity, temperature, presence of external alkalis and salt solutions are also considered important aspects that control the rate of ASR and corresponding expansion. Relative humidity higher than $80 \%$ is necessary to initiate ASR. It was also investigated that higher temperature accelerates ASR [Neville 1981]. Presence of external alkali solutions also enhances the rate of expansion. Combination of both is widely accepted and applied as a technique to evaluate the reactivity of the aggregate in mortar bars, as mentioned before. Exposure to salt solutions can be even more aggressive than to alkali solutions because they release hydroxyl ions. $\mathrm{NaCl}$ is actively converted to Friedel's salt and raises the $\mathrm{pH}$ of concrete in pore solution. It also increases the solubility of silica thereby increasing the rate of reaction [Chatterji et al. 1987]. The ASR damage can be observed in the form of map cracking on the surface of concrete. Several field investigations revealed the maximum range of crack width can vary from 0.1-10 mm in severe conditions [Neville 1995; Swamy 1994; Vivian 1990].

The use of steel fibers in concrete has proved to enhance structural strength, decrease permeability and control crack width. It has also been investigated that they control expansion and reduce cracking due to ASR depending on fiber type and volume fraction, as reported by various researchers [Haddad and Smadi 2003; Bektas et al. 2005]. ASR gradually increases tortuosity in concrete, allowing other deleterious substances such as sulphates, chlorides etc. to penetrate inside. The process is followed by corrosion of reinforcement, which eventually degrades the durability and serviceability of a concrete structure. The development of prevention techniques need to be considered in order to prevent damage due to coupled effects of two or more deterioration processes. This research is an attempt to examine such coupled effects of ASR and corrosion due to chloride ion penetration in steel fiber reinforced concrete. Normal strength concrete specimens fabricated with low alkali cement, river sand and a reactive coarse aggregate were prepared. The effect of addition of normal and ultra-high strength steel fibers with variation in temperature was done to investigate the level of damage at each temperature range.

\section{EXPERIMENTAL INVESTIGATION}

\section{Experimental study}

Plain concrete and two types of fiber reinforced concrete were used for the experiment. Normal strength plain concrete (NC) and two types of fiber reinforced concrete (SFRC and UHSFRC) having 35-40 MPa target compressive strength at 28 days were used. Normal and ultra-high strength steel fibers having different shapes, anchorage strengths and ductility were selected as shown in Fig. 1. Parameters such as length, aspect ratio and volume fraction were kept constant for the concrete mixes. Twenty seven prisms: $40 \mathrm{~cm}$ long, $10 \mathrm{~cm}$ wide, $10 \mathrm{~cm}$ high and fifty four cylinders: $10 \mathrm{~cm}$ in diameter and $20 \mathrm{~cm}$ high, were fabricated. The experiments were carried out at the temperatures of $5{ }^{\circ} \mathrm{C}, 25^{\circ} \mathrm{C}$ and $40{ }^{\circ} \mathrm{C}$.

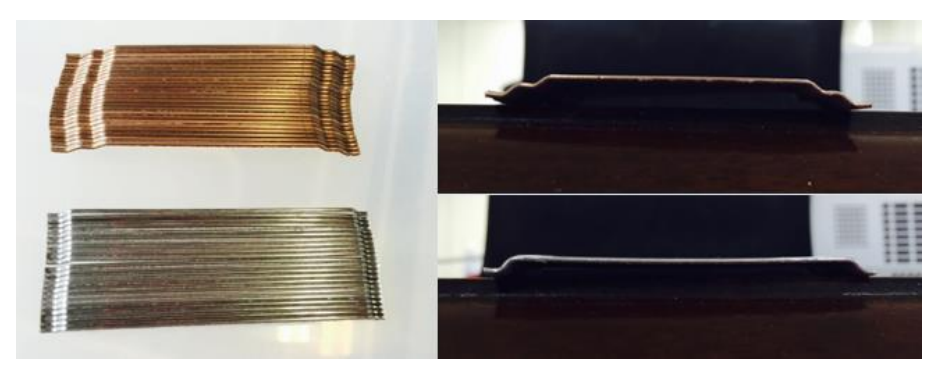

Figure 1. Normal and ultra high strength steel fibers 


\section{Materials and mix proportion of concrete}

Low alkali portland cement containing total sodium oxide equivalent $\left(\mathrm{Na}_{2} \mathrm{O}_{\text {eq }}\right)$ of $0.48 \%(<0.6 \%$ limit as per limit; ASTM C 150) was used. River sand as fine aggregate and reactive coarse aggregate from local source were used. The reactivity of coarse aggregate was confirmed by JIS A 1145 (2007).

The total alkali content of concrete expressed as sodium oxide equivalent $\left(\mathrm{Na}_{2} \mathrm{O}_{\text {eq }}\right)$ was $2.1 \mathrm{~kg} / \mathrm{m}^{3}$ of concrete. The reactive aggregate had water absorption of $2.28 \%$ and bulk density of $1540 \mathrm{~kg} / \mathrm{m}^{3}$. Chemical compositions of the fine and coarse aggregate, properties of steel fiber and mix design are listed in Tables 1,2 and 3 respectively.

Table 1. Chemical composition

\begin{tabular}{|c|c|c|}
\hline $\begin{array}{c}\text { Chemical Analysis } \\
\text { (Oxide) }\end{array}$ & $\begin{array}{c}\text { Coarse } \\
\text { Aggregate }\end{array}$ & $\begin{array}{c}\text { Fine } \\
\text { Aggregate }\end{array}$ \\
\hline $\mathrm{Fe}_{2} \mathrm{O}_{3}(\%)$ & 7.67 & 20.342 \\
\hline $\mathrm{K}_{2} \mathrm{O}(\%)$ & 2.06 & 2.323 \\
\hline $\mathrm{CaO}(\%)$ & 7.62 & 8.210 \\
\hline $\mathrm{SiO}_{2}(\%)$ & 59.9 & 65.86 \\
\hline $\mathrm{Al}_{2} \mathrm{O}_{3}(\%)$ & 16.8 & - \\
\hline $\mathrm{MgO}(\%)$ & 1.93 & - \\
\hline $\mathrm{Na}_{2} \mathrm{O}(\%)$ & 2.81 & - \\
\hline $\mathrm{MnO}(\%)$ & - & 0.4289 \\
\hline $\mathrm{TiO}_{2}(\%)$ & - & 2.0882 \\
\hline $\begin{array}{l}\text { Alkali content } \\
\left(\mathrm{Na}_{2} \mathrm{O}_{\mathrm{eq}}\right)\end{array}$ & 0.455 & 0.125 \\
\hline
\end{tabular}

Table 2. Steel fibers properties

\begin{tabular}{|c|c|c|}
\hline Type of Steel Fiber & $\begin{array}{c}\text { Normal } \\
\text { Strength }\end{array}$ & $\begin{array}{c}\text { Ultra- } \\
\text { High } \\
\text { Strength }\end{array}$ \\
\hline Length (mm) & 60 & 60 \\
\hline Diameter (mm) & 65 & 65 \\
\hline Young's Modulus (GPa) & 210 & 210 \\
\hline Tensile Strength (GPa) & 1.16 & 2.36 \\
\hline
\end{tabular}

Table 3. Mix design

\begin{tabular}{|c|c|c|c|c|c|c|}
\hline & $\begin{array}{l}\text { Cement } \\
\left(\mathrm{kg} / \mathrm{m}^{3}\right)\end{array}$ & $\begin{array}{c}\text { Fine } \\
\text { Aggregate } \\
\left(\mathrm{kg} / \mathrm{m}^{3}\right)\end{array}$ & $\begin{array}{c}\text { Coarse } \\
\text { Aggregate } \\
\left(\mathrm{kg} / \mathrm{m}^{3}\right)\end{array}$ & $\begin{array}{c}\text { Water } \\
\left(\mathrm{kg} / \mathrm{m}^{3}\right)\end{array}$ & $\begin{array}{c}\text { Amount of } \\
\text { Fiber } \\
\left(\mathrm{kg} / \mathrm{m}^{3}\right)\end{array}$ & $\begin{array}{c}\text { Target } \\
\text { Compressive } \\
\text { Strength (MPa) }\end{array}$ \\
\hline $\mathrm{NC}$ & \multirow{3}{*}{318} & \multirow{3}{*}{818} & \multirow{3}{*}{1093} & \multirow{3}{*}{181} & 0 & \multirow{3}{*}{$35-40$} \\
\hline SFRC & & & & & 15 & \\
\hline UHSFRC & & & & & 15 & \\
\hline
\end{tabular}

\section{Exposure}

Concrete prisms and cylinders were casted and cured in water for 14 days at room temperature. They were then fully submerged in $1 \mathrm{~N} \mathrm{NaOH}$ solution in order to accelerate ASR. After ten weeks, all the specimens were taken out. The specimens were surface dried to remove excess $\mathrm{NaOH}$ from the surface. They were then shifted to $3 \% \mathrm{NaCl}$ solution (by mass) for ten more weeks as shown in Fig. 2. These exposure processes are summarized in Table 4. 

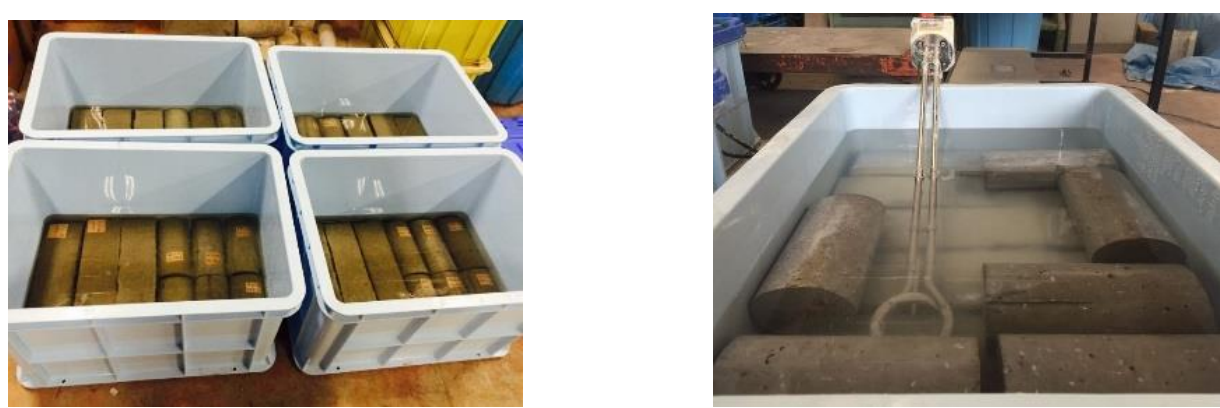

Figure 2. Alkali exposure followed by immersion ino $\mathrm{NaCl}$ solution

Table 4. Summary of experiment

\begin{tabular}{|c|c|c|c|c|}
\hline \multirow{2}{*}{$\begin{array}{l}\text { Type of } \\
\text { Concrete }\end{array}$} & \multirow[b]{2}{*}{$\begin{array}{l}\text { Number of } \\
\text { Specimens }\end{array}$} & \multicolumn{2}{|c|}{ Duration } & \multirow[b]{2}{*}{$\begin{array}{c}\text { Temperature } \\
\text { of Exposure } \\
\left({ }^{\circ} \mathrm{C}\right)\end{array}$} \\
\hline & & $\begin{array}{c}\text { Exposure } \\
\text { to } \mathrm{NaOH} \\
\text { Solution }\end{array}$ & $\begin{array}{l}\text { Exposure } \\
\text { to } \mathrm{NaCl} \\
\text { Solution }\end{array}$ & \\
\hline $\mathrm{NC}$ & \multirow{3}{*}{$\begin{array}{c}3 \text { Prisms } \\
\text { and } 6 \\
\text { Cylinders }\end{array}$} & \multirow{3}{*}{10 Weeks } & \multirow{3}{*}{10 Weeks } & \multirow{3}{*}{$5,25,40$} \\
\hline SFRC & & & & \\
\hline UHSFRC & & & & \\
\hline
\end{tabular}

Plastic tanks that can tolerate high alkali environment were used to submerge the specimens. Temperature of $40 \pm 2{ }^{\circ} \mathrm{C}$ was maintained using electric heater having a calibrated automatic temperature control dial with the range of 30 to $80{ }^{\circ} \mathrm{C}$. Temperature of $5^{\circ} \mathrm{C}$ was achieved using a separate chamber equipped with temperature control unit.

\section{Loading test procedure}

After the alkali and salt water exposure was completed, the specimens were removed from the solution and air dried for 24 hours. The compressive strength test, split tensile strength test and three point bending test were conducted on concrete cylinders and prisms according to ASTM C 39, ASTM C 496 and ASTM C 78 , respectively.

\section{RESULTS AND DISCUSSION}

\section{Mechanical properties}

Compressive strength: Compressive strength testing machine with a capacity of $980 \mathrm{kN}$ was used to determine the compressive strength of the damaged specimens. The specimens were loaded at the rate of $4.6 \mathrm{kN} / \mathrm{mm}^{2}$ per second. A comparison of the initial strength and final strength (damaged cylinders) showed an increase in compressive strength for NC, SFRC and UHSFRC at all the temperatures (Fig. 3). The highest increase was recorded for NC followed by UHSFRC. SFRC showed a slight decrease in compressive strength at $25{ }^{\circ} \mathrm{C}$ (Fig. 4). The damage due to ASR decreases the compressive strength in concrete, as observed previously by several researchers [Marzouk and Langdon 2003; Swamy and Al-Asali 1990]. However, the restraint expansion in the less reactive layer near the surface of the cylinder can result in strength gain [Jones and Clark 1997]. The compressive strength also depended on the test method used to evaluate the compressive strength. It was observed previously that cylinder compression test was insensitive to damage by ASR. The results from cylinders having the height-to-diameter ratio of 3 and less, substantially underestimated the level of damage due to ASR [Jones and Clark 1997]. Hence, the true uniaxial compressive strength of the ASR and chloride damaged specimen can only be estimated 


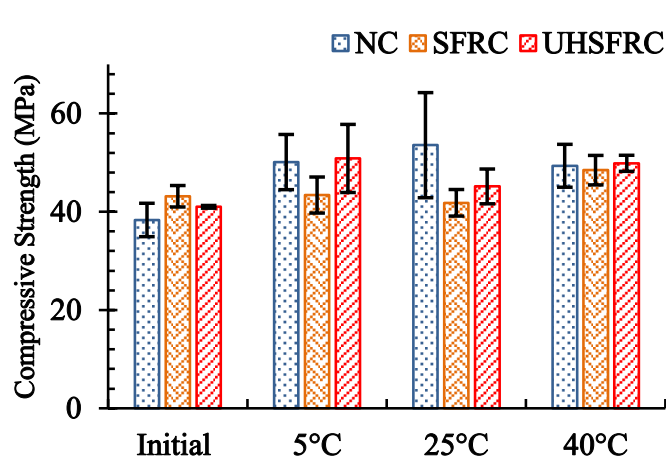

Figure 3. Average compressive strength
of alkali-silica and chloride damaged
cylinders

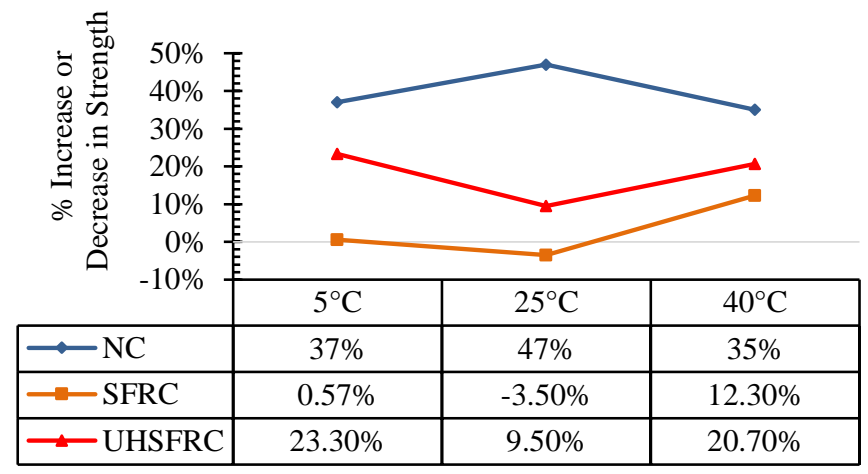

Figure 4. Percentage increase in
average compressive strength of ASR
and chloride damaged cylinders

when the difference in restraint expansion in different layers of concrete is negligible. The compressive strength of concrete is also dependent on the material properties of the mix. Addition of fiber in concrete should improve the compressive strength which was found contradictory to the results obtained in this case. Endurance of NC was increased due to improved microstructure and CSH hydration which resulted in higher compressive strength than the other two mix types. UHSFRC showed higher strength gain as compared to SFRC which can be contributed to the increased anchorage strength of ultra-high strength steel fiber.

Split tensile strength: Increment in split tensile strength for ASR and chloride damaged cylinders was observed. Figure 5 shows the average and percentage increase in strength for different types of concrete mixes. Similar to the compressive strength, the split tensile strength of concrete also depends on the type of test used and can vary for the pressure tension test, modulus of rupture test and split tensile strength test. Particularly, the split tensile strength test is sensitive to ASR, as it purely depends on the orientation of surface cracking [Jones and Clark 1997]. Roughly stating the percentage increase in strength for damaged cylinders was from $0.6-25 \%$ as shown in Fig. 6 . Closely analysing the results with the deviated values, the following observations were made:

1. For the plain concrete cylinders; the split tensile strength increased at $5{ }^{\circ} \mathrm{C}$ and $25{ }^{\circ} \mathrm{C}$ whereas, it was almost the same at $40{ }^{\circ} \mathrm{C}$. Improved CSH hydration at these two temperatures resulted in increased strength while having ASR and chloride ion damage. At $40{ }^{\circ} \mathrm{C}$, the rate of damaged increased and the overall strength remained almost the same.

2. Correlating the deviated values in SFRC, it was found that the damage due to ASR and chloride ion penetration was overcome by addition of the fiber, as it enhanced the tensile capacity. Therefore, split tensile strength remained almost the same in all the cases $\left(5^{\circ} \mathrm{C}, 25^{\circ} \mathrm{C}\right.$, and $\left.40^{\circ} \mathrm{C}\right)$.

3. Similarly, in UHSFRC cylinder specimens, split tensile strength remained almost the same, except at $25{ }^{\circ} \mathrm{C}$. This abnormal trend could be the result of variation in fiber location.

First crack strength: Deflection control universal testing machine was used to conduct three-point bending test according to ASTM C 78. Concrete prisms were loaded at the rate of $0.1 \mathrm{~mm} / \mathrm{min}$ until fracture. The first crack strength of each specimen was recorded accordingly. Figure 7 shows the peak load and corresponding first crack strength of the prisms that were undamaged, prisms damaged with ASR and prisms damaged with both ASR and chloride ion penetration. 


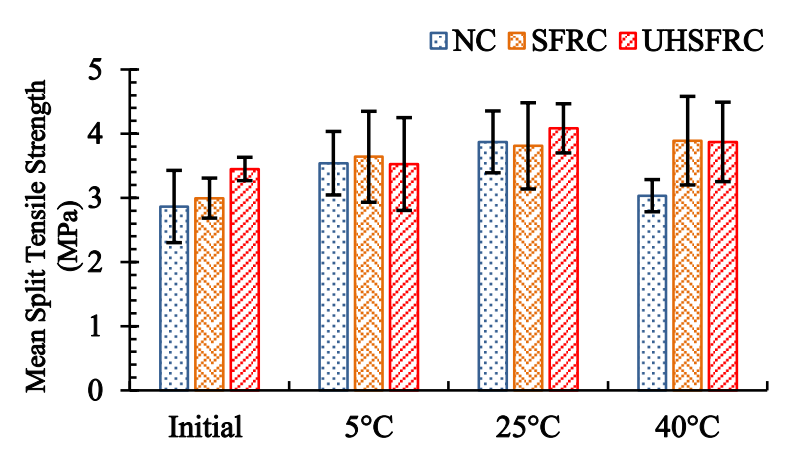

Figure 5. Average split tensile strength of alkali-silica and chloride damaged cylinders

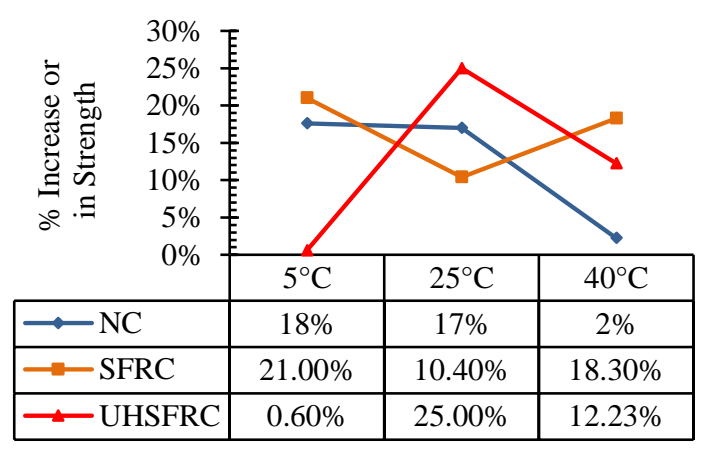

Figure 6. Percentage increase in average split tensile strength of ASR and chloride damaged cylinders

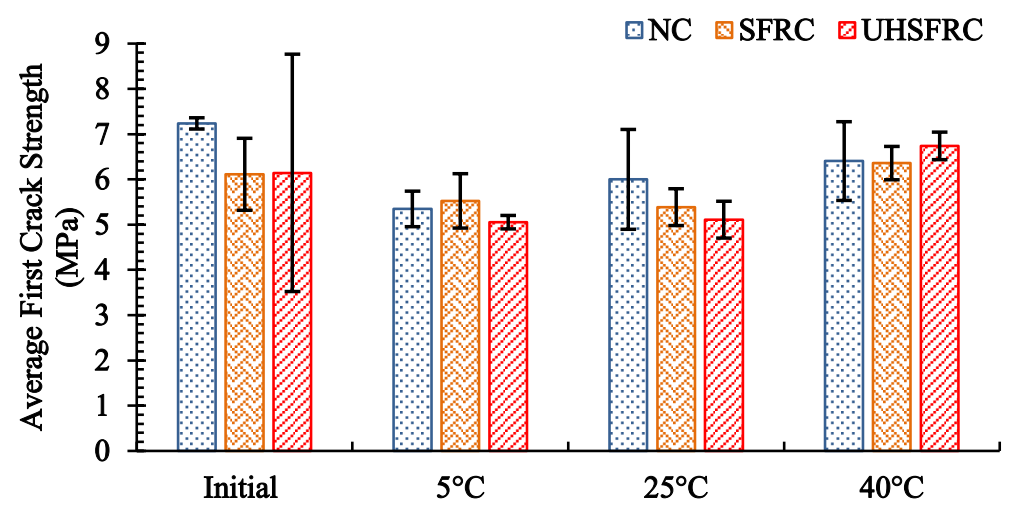

Figure 7. First crack strength of ASR and chloride damaged prisms

\section{Effect of alkali and chloride environments}

The average first crack strength for all the specimens decreased after ASR and chloride exposure, as expected. An increase in strength for the specimens exposed to only alkali solution was observed. The same trend was observed in all types of the concrete regardless of temperature variation. The ratio of final strength (damaged) to initial strength (undamaged) termed as the strength reduction unit was used to analyse the changed strength (Fig. 8). The increase in strength can be explained due to high calcium concentration in ASR gel. Calcium hydroxide produced in hydration of cement contributed to ASR reaction and production of ASR gel. Cations $\left(\mathrm{Na}^{+}\right)$and hydroxyl ions penetrating the aggregate reacted with silica in the aggregate, which then reacted with the calcium ions to get calcium alkali silicate gel. As the reaction progressed, the concentration of alkali in pore solution decreased with increase in calcium concentration. The result was the production of ASR gel rich in calcium. Production of non swelling, high calcium concentrated gel as a result of safe reaction was hypothesized before [Powers and Steinour 1955]. It was derived that safe reaction will begin and continue without expansion in concrete if the initial $\mathrm{Na}_{2} \mathrm{O}_{\text {eq }}$ concentration in cement is less than $0.6 \%$. This hypothesis was based on the study of reaction between opal, calcium and alkalis in mortar and concrete. Decrease in the first crack strength by chloride environment, once the concrete was already deteriorated by ASR can be interpreted to the aggressive nature of $\mathrm{NaCl}$ solution against ASR. It is believed that alkali salts aggravate the reaction. Sodium chloride is converted to Friedel's salt giving hydroxide in pore solution which raises the $\mathrm{pH}$. As the concentration of hydroxide increases, the dissolution of silica also increases. The equation is given as: 


$$
\mathrm{C}_{3} \mathrm{~A}+2 \mathrm{NaCl}+\mathrm{Ca}(\mathrm{OH})_{2}+10 \mathrm{H}_{2} \mathrm{O} \longrightarrow \mathrm{C}_{3} \mathrm{~A} \cdot \mathrm{CaCl}_{2} \cdot 10 \mathrm{H}_{2} \mathrm{O}+2 \mathrm{Na}^{+}+2(\mathrm{OH})^{-}
$$

Hence the addition of salt solution undoubtly increases the rate of ASR. This resulted in more damage and reduction in first crack strength.

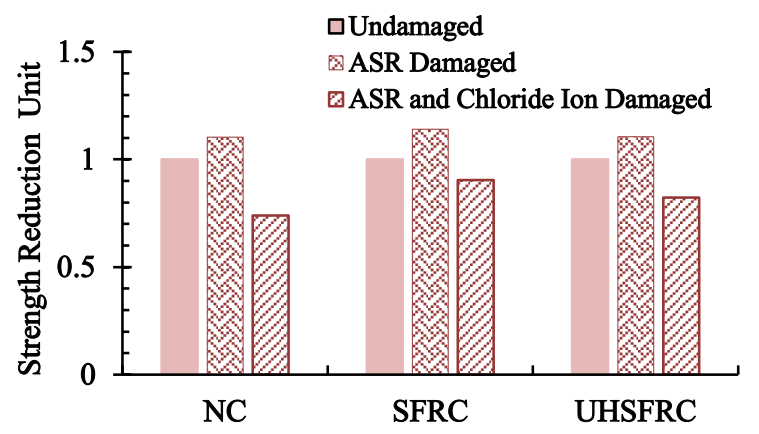

(i) $5^{\circ} \mathrm{C}$

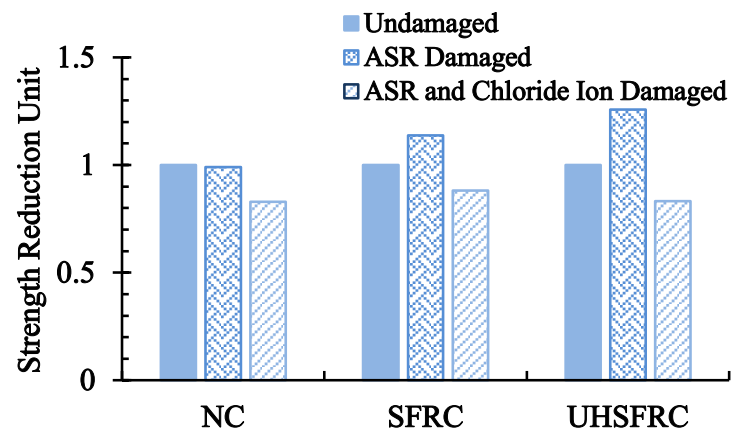

(ii) $25^{\circ} \mathrm{C}$

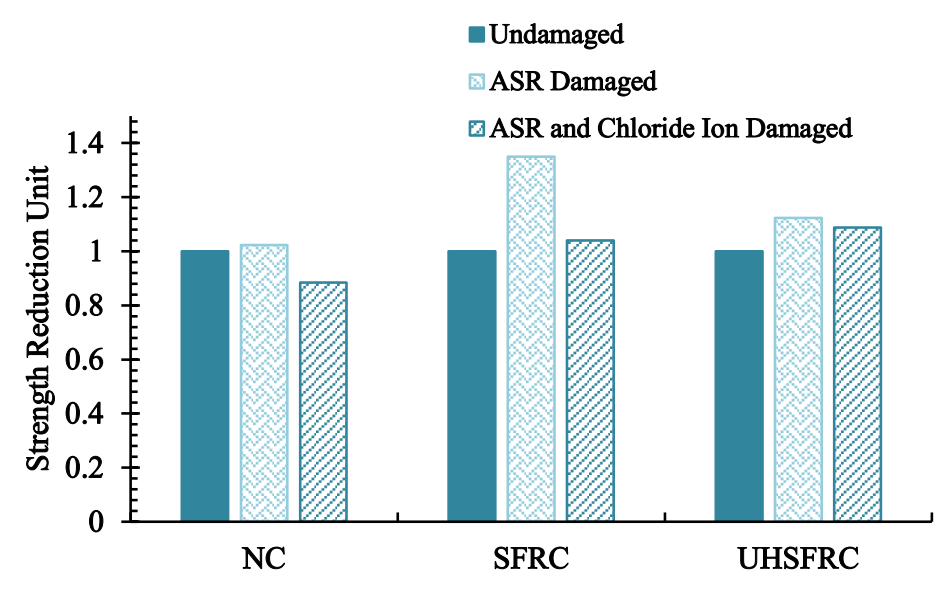

(iii) $40^{\circ} \mathrm{C}$

Figure 8. Strength variation in ASR damaged, ASR and chloride damaged prisms at (i)

\section{Effect of mix variation}

$$
5^{\circ} \mathrm{C} \text {, (ii) } 25^{\circ} \mathrm{C} \text {, and (iii) } 40^{\circ} \mathrm{C}
$$

Addition of fiber to concrete increases its flexural capacity. In this respect UHSFRC should have shown outstanding performance among the three mixes. The results obtained by analysing damaged specimens showed an irregular strength reduction pattern at different temperature ranges. Percentage decrease in strength is shown in Fig. 9. Strength reduction of $26.2 \%$ as compared to $17.2 \%$ and $21.5 \%\left(5{ }^{\circ} \mathrm{C}\right) ; 17.08 \%$ as compared to $19.2 \%$ and $16.8 \%\left(25^{\circ} \mathrm{C}\right)$ and $11.48 \%$ as compared to $4.7 \%$ and $-8.8 \%\left(40{ }^{\circ} \mathrm{C}\right)$ were recorded among the three types of concrete mixes. The strength reduction difference of $9 \%, 4.7 \%$ at $5^{\circ} \mathrm{C}$ and $6.8 \%$ and $20.3 \%$ at $40^{\circ} \mathrm{C}$ found among SFRC, UHSFRC and NC clearly indicated better performance of fiber reinforced concrete in combined alkali and chloride ion exposure. Whereas at $25{ }^{\circ} \mathrm{C}, \mathrm{SFRC}$ and UHSFRC showed minimal differences in strength loss; $-2.12 \%$ and $0.28 \%$.

The improved performance of fiber reinforced concrete depends on fiber orientation and shape. These were found to be prominent properties that can determine the level of damage in the two mix types. Fibers are randomly oriented in the concrete mix; moreover, the shape of fiber can change its bond strength within concrete. This resulted in unusual trend for strength loss. This is also accountable for slight increase in strength for UHSFRC at $40{ }^{\circ} \mathrm{C}$ apart from the deviation in values. 


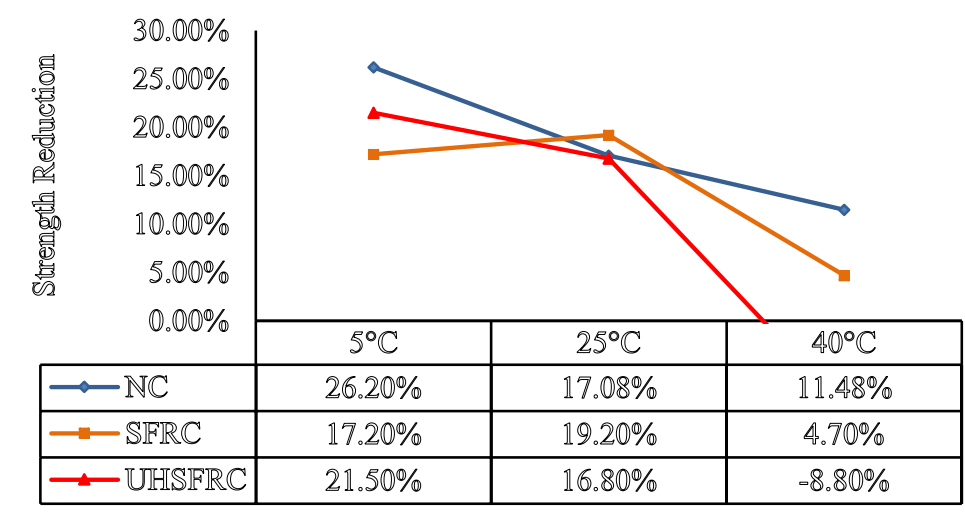

Figure 9. Percentage strength variation in ASR and chloride damaged prisms at various temperatures

\section{Effect of Temperature}

It has been studied that the temperature variation from $10-38{ }^{\circ} \mathrm{C}$ accelerated ASR in alkali environment [Neville 1981]. Whereas, in chloride environment the rate of reaction increased at $38{ }^{\circ} \mathrm{C}, 50{ }^{\circ} \mathrm{C}$ and $80{ }^{\circ} \mathrm{C}$ and decreased at $22{ }^{\circ} \mathrm{C}$ [Helmuth et al. 1993]. In the present case, the same temperature range for two different set of exposures was used. NC showed linear strength reduction from 5 to $40{ }^{\circ} \mathrm{C}$ (Fig. 9). This was attributed to higher level of damage at high temperature. However, the strength reduction trend in case of UHSFRC and SFRC did not follow a regular pattern. Apart from fiber properties, there are many other factors that control the level of damage due to ASR and chloride solution exposure. The actual mechanism and reaction kinetics can be related to physical, chemical and material properties. For instance porosity, permeability, diffusion of chloride ion, size of reactive aggregate, concentration of solution, cement hydration, alkali content from cement, restraint expansion and bond strength of fiber can substantially change results. Further studies relating strength loss at each temperature range with respect to each property is required for justification.

\section{Visual observations}

Surface crack width measurement was done on one fourth part $(10 \mathrm{~cm})$ of the ASR damaged prisms. The area was selected as a representative from each prism. All the four sides of the prism were measured using a portable optical microscope. Figure 10 demonstrates the selection of the representative area. Measurements for each prism displaying range of crack width, maximum and average crack width are listed in Table 4.
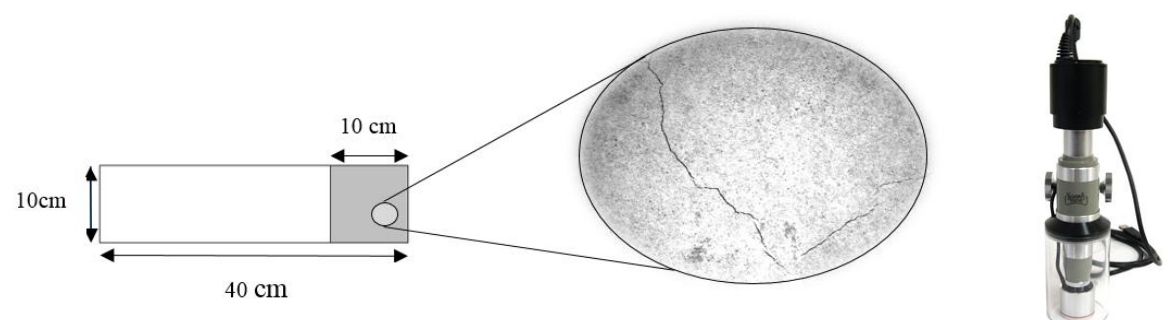

Figure 10. Crack width measurement using optical microscope

Transition in temperature from 5 to $40{ }^{\circ} \mathrm{C}$ was accountable for increased mean crack width from 18.2 to $22.61 \mu \mathrm{m}$ in NC, as the level of damage increased. Declining trend from 17.51 to $16.8 \mu \mathrm{m}$ and 16.5 to $16.16 \mu \mathrm{m}$ was observed in case of SFRC and UHSFRC at $5{ }^{\circ} \mathrm{C}$ and $25^{\circ} \mathrm{C}$. The higher anchorage 
strength of UHSFRC as compared to SFRC and NC was able to control cracking among the three types of concrete at $5{ }^{\circ} \mathrm{C}$ and $25{ }^{\circ} \mathrm{C}$ (Fig. 11). The least mean crack width was $16.5 \mu \mathrm{m}$ and $16.16 \mu \mathrm{m}$ for UHSFRC. At $40{ }^{\circ} \mathrm{C}$, UHSFRC showed the highest mean crack width among all mixes with a lot of variations in measurements. Fibers are randomly located in the concrete mix. Hence their crack bridging capacity is not the same in every direction. Moreover, induction of cracks is also dependent on the reaction kinetics at different locations, particle sizes and distributions in the matrix. Therefore, this abnormal behavior was observed.

Table 4. Maximum and mean crack widths

\begin{tabular}{|c|c|c|c|c|c|c|}
\hline \multirow{2}{*}{$\begin{array}{c}\text { Type } \\
\text { of } \\
\text { Mix }\end{array}$} & $\begin{array}{c}\text { Temperature } \\
\left({ }^{\circ} \mathrm{C}\right)\end{array}$ & $\begin{array}{c}\text { Number of } \\
\text { Measurements }\end{array}$ & $\begin{array}{c}\text { Crack Width } \\
\text { Range }(\mu \mathrm{m})\end{array}$ & $\begin{array}{c}\text { Max. } \\
\text { Crack } \\
\text { Width } \\
(\mu \mathrm{m})\end{array}$ & $\begin{array}{c}\text { Mean Crack } \\
\text { Width }(\mu \mathrm{m})\end{array}$ & $\begin{array}{c}\text { Standard } \\
\text { Deviation }\end{array}$ \\
\hline \multirow{3}{*}{ NC } & 5 & 41 & $9.76-40.24$ & 40.24 & 18.2 & 1.302 \\
\cline { 2 - 7 } & 25 & 37 & $8-37.5$ & 37.5 & 18.39 & 1.311 \\
\hline \multirow{3}{*}{ SFRC } & 40 & 42 & $8.76-49.04$ & 49.04 & 22.61 & 1.680 \\
\cline { 2 - 7 } & 4 & 44 & $7.33-34.42$ & 34.42 & 17.51 & 1.456 \\
\hline \multirow{3}{*}{$\begin{array}{c}\text { HSFR } \\
\text { C }\end{array}$} & 25 & 40 & $5.47-34.6$ & 34.6 & 16.8 & 1.508 \\
\cline { 2 - 7 } & 40 & 41 & $6.33-44.9$ & 44.9 & 20.74 & 1.883 \\
\hline
\end{tabular}

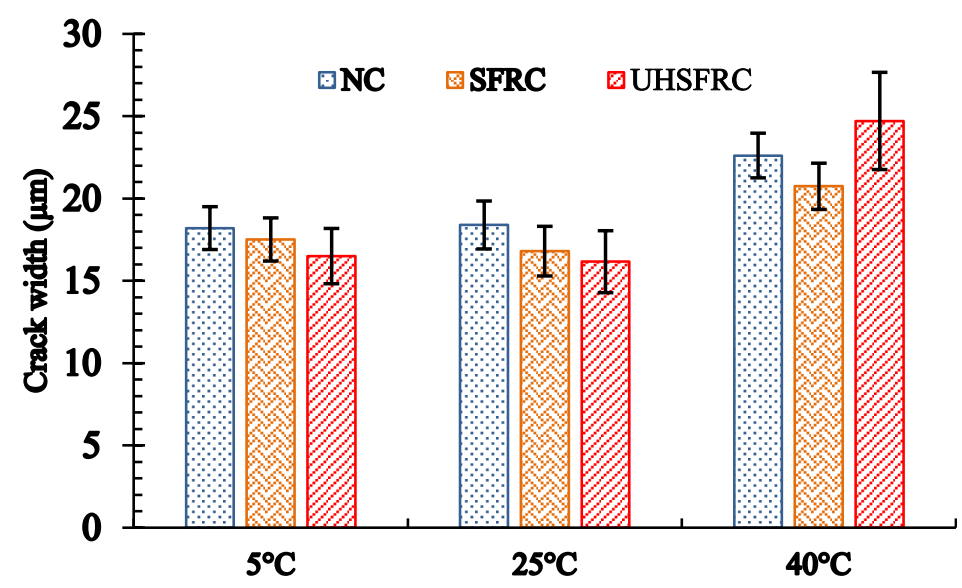

Figure 11. Mean crack width of ASR damaged prisms 


\section{CONCLUSION}

The following general conclusions can be drawn from the study provided in the paper:

- Limitation of total alkali content of $3 \mathrm{~kg} / \mathrm{m}^{3}\left(\mathrm{Na}_{2} \mathrm{O}_{\text {eq }}\right)$ in normal strength concrete to control damage due to ASR failed to prevent damage; in case of coupled effect of ASR and chloride environment.

- Addition of fiber (even < 1\%) can improve concrete performance against ASR and chloride environment. SFRC and UHSFRC performed better than NC.

- The mechanisms involved in deterioration due to ASR and chloride environment are much more complex and are dependent on many properties such as; reaction kinetics, porosity, permeability, diffusion of chloride ion, size of reactive aggregate, concentration of solution, cement hydration, alkali content from cement, restraint expansion, fiber properties, and temperature. Extensive studies relating temperature and factors that accelerate or decelerate reaction kinetics are required.

- Restraint expansion in less reactive layer near the surface of the cylinder resulted in strength gain. Improved strength for damaged NC, SFRC and UHSFRC was observed (NC $>$ UHSFRC $>$ SFRC). CSH hydration in NC and higher anchorage in UHSFRC were the reasons of higher increased strength.

- Split tensile strength test yielded increased strength in NC, while it remained almost the same in SFRC and UHSFRC. However the test is extremely sensitive, and not appropriate to evaluate tensile strength in deteriorated specimens, as a lot of variation in results was observed.

- Development of 'safe reaction' and production of calcium rich gel for prisms exposed to alkali solution resulted in increase in strength. The idea correlates with the Power and Steinour's hypothesis. Later on, exposure to chloride environment increased the rate of deterioration by raising $\mathrm{pH}$ and dissolving more silica. Therefore, the tensile strength dropped in almost every case.

- Fiber reinforced concrete can prevent damage much better than NC as strength loss in SFRC and UHSFRC was less than NC. However, this depends on fiber orientation and shape as the mean crack width was reduced from 18.2-16.5 $\mu \mathrm{m}\left(\right.$ at $\left.5^{\circ} \mathrm{C}\right)$ and $18.39-16.16 \mu \mathrm{m}\left(25^{\circ} \mathrm{C}\right)$ by using double hooked ultra-high strength fibers.

\section{REFERENCES}

ASTM C 33. "Standard Specification for Concrete Aggregates."

ASTM C 39. "Compressive Strength of cylindrical concrete specimens."

ASTM C 78. "Standard Test Method for Flexural Strength of Concrete (Using Simple Beam with ThirdPoint Loading)."

ASTM C 150. "Standard Specification for Portland Cement."

ASTM C 289. "Standard Test Method for Potential Alkali-Silica Reactivity of Aggregates (Chemical Method)."

ASTM C 295. "Standard Guide for Petrographic Examination of Aggregates for Concrete."

ASTM C 496. "Standard Test Method for Splitting Tensile Strength of Cylindrical Concrete Specimens."

ASTM C 1260. "Standard Test Method for Potential Alkali Reactivity of Aggregates (Mortar Bar Method)."

Bektas, F., Turanli. L. and Ostertag, C. P. (2006). "New Approach in Mitigating Damage caused by alkali silica reaction." Journal of Material Science, 41 (17), 5760-5763.

Chatterji, S., Thaulow, N., and Jensen, A. D. (1987). "Studies of Alkali Silica Reaction Part IV: Effect of Different Alkali Salt Solutions on Expansion." Cement and Concrete Research, 17 (5), 777-783.

Farny. J. A. and Kerkhoff, B. (2007). "Diagnosis and Control of Alkali Aggregate Reactions in Concrete," Portland Cement Association, 25. 
Haddad, R. H. and Smadi, M. M. (2003). "Role of fibers in controlling unrestrained expansion and arresting cracking in Portland cement concrete undergoing alkali silica reaction." Cement and Concrete Research, 34(1), 103-108.

Helmuth, R., Stark, D., and Diamond, S. (1993). “Alkali Silica Reactivity: An Overview of Research." Strategic Highway Research Program, Publication no. SHRP-C-342.

JIS A 1145 (2007). "Chemical Test for Alkali Silica Reactivity."

Jones, A. E. K. and Clark, L. A. (1996). "The effects of restrained expansion on the assessment of structures with ASR.” TRI Report, 161, Crowthorne.

Marzouk, H. and Langdon, S. (2003). "The effect of alkali aggregate reactivity on mechanical properties of high and normal strength concrete." Cement and Concrete Composites, 25, 549-556.

Neville, A. M. (1981). "Properties of Concrete.” Third Edition, Longman Scientific \& Technical.

Neville, A. M. (1996). "Properties of Concrete." Fourth Edition, John Wiley \& Sons.

Powers, T. C. and Steinour, H. H. (1955). "An Interpretation of Some Published Researchers on AlkaliAggregate Reaction. Part 2:-A Hypothesis Concerning Safe and Unsafe Reactions with Reactive Silica in Concrete." Journal of the American Concrete Institute, 26(8), 785-811.

Swamy, R. N. (1994). "Alkali aggregate Reaction - The Bogeyman of concrete, Concrete Technology; Past, Present and Future." Proceedings of V. Mohan Malhotra Symposium, ACI, 105-129.

Swamy, R. N. and Al-Asali, M. M. (1990). "Control of alkali silica reaction in reinforced concrete beams." ACI Materials Journal, 87(1), 38-46.

Vivian, H. E. (1992). "The Mechanism of Alkali Aggregate Reaction." Proceedings of the $9^{\text {th }}$ International Conference on Alkali Aggregate Reaction in Concrete, London, 1085-1106. 